\title{
BULLYING AND VERBAL-NONVERBAL COMMUNICATION AMONG A GROUP OF COLLEGE STUDENTS
}

\author{
Siti Khadijah \\ Program Studi Ilmu Komunikasi FKSB Universitas Islam 45 \\ kh4d1j4h@gmail.com
}

\begin{abstract}
Bullying is one of problems of Universities in Indonesia. In 2006, there were 29 cases of physical violence, 67 cases of sexual violence, and 96 ases of psychic violence in college. This research aimed to analyse bullying cases among a group of college students from the point of views of verbal and non-verbal communications. Using qualitative method, there were acts of bullying in the form of verbal communication experienced by victims in the form of harsh words that belittle the victim, scolding, screaming, giving negative nickname even a month-monthly friend of a class, and done in front of the crowd. While harassment in the form of nonverbal communication is a cynical view of the perpetrator against the victim, the view of degrading the victim by considering the victim as a "fool", making the distance with the victim by not including victims in the chat group, not invited to take a walk, be kept in class. In addition, the victim also got a kick, spit on, thrown with goods. Negative impacts are anxiety, quarreling with abusers, and declining learning achievement.
\end{abstract}

Keywords: Verbal non-verbal communications, bullying, students

\begin{abstract}
ABSTRAK
Perundungan merupakan salah satu masalah di beberapa universitas di Indonesia. Pada tahun 2006, ada 29 kasus kekerasan fisik terjadi di universitas, 67 kasus kekerasan seksual dan 96 kasus kekerasan psikis. Penelitian ini bertujuan untuk menganalisis kasus perundungan di antara sekelompok mahasiswa dari sudut pandang komunikasi verbal dan nonverbal. Dengan menggunakan metode kualitatif hasil penelitian menunjukkan bahwa tindakan perundungan dalam bentuk komunikasi verbal yang dialami oleh korban berupa kata-kata kasar yang meremehkan korban, cacian, teriakan, memberi julukan negatif bahkan menjadi bulan-bulanan teman satu kelas, dan dilakukan dihadapan orang banyak. Sedangkan perundungan dalam bentuk komunikasi nonverbal berupa pandangan sinis pelaku terhadap korban, pandangan merendahkan korban dengan menganggap korban sebagai "orang bodoh", membuat jarak dengan korban dengan tidak mengikutsertakan korban dalam chat group, tidak diajak berdarmawisata, dijauhkan di kelas. Selain itu korban juga pernah mendapat tendangan, diludahi, dilempar dengan barang. Dampak negatif yang ditimbulkan adalah perasaan cemas, bertengkar dengan pelaku perundungan, dan menurunnya prestasi belajar.
\end{abstract}

Kata-kata Kunci: Komunikasi non verbal -verbal, perundungan, mahasiswa 


\section{PENDAHULUAN}

Aksi perundungan (bullying) dapat berujung pada tindakan kekerasan dalam dunia pendidikan seperti di perguruan tinggi yang marak terjadi di Indonesia. Pemberitaan di salah satu media nasional pada 2014 memuat peristiwa kekerasan di Sekolah Tinggi Ilmu Pelayaran (STIP) yang merenggut nyawa salah seorang mahasiswa bernama Dimas Dikita Handoko (Tanjung, 2014). Peristiwa kekerasan tersebut bukanlah yang pertama kali terjadi. Selain itu, ada peristiwa kekerasan di Institut Pemerintahan Dalam Negeri (IPDN) yang dilakukan oleh senior kepada junior pada 2007 (Yusuf, 2007). Berbagai kasus kekerasan di perguruan tinggi menambah panjang daftar jumlah korban yang berjatuhan di lembaga kependidikan dan hal ini seakan mengindikasikan bahwa dunia pendidikan di Tanah Air telah menebar teror bagi anak didiknya sendiri. Tindakan kekerasan sendiri bisa dikategorikan kepada tindakan perundungan. Tindakan perundungan terhadap sesama, terlebih yang terjadi di lingkungan institusi pendidikan, terutama di ranah pendidikan tinggi seperti universitas menjadi keprihatinan berbagai kalangan.

Tidak hanya di Indonesia, perundungan juga terjadi di negara maju seperti Jepang. Survei yang dilakukan pada 2004 oleh Departemen Pendidikan Jepang menyebutkan bahwa terdapat 24.898 kasus perundungan di perguruan tinggi. Dari jumlah tersebut, 12.307 kasus terjadi di perguruan tinggi swasta (PTS). Pada 2006, di Indonesia terdapat 247 kasus kekerasan fisik (29 kasus terjadi di perguruan tinggi), 426 kasus kekerasan seksual (67 kasus di perguruan tinggi), dan 451 kasus kekerasan psikis (96 kasus di perguruan tinggi) (Simbolon, 2012). Menurut data dari KPAI, saat ini kasus perundungan menduduki peringkat teratas pengaduan masyarakat. Dari 2011 hingga Agustus 2014, KPAI mencatat 369 pengaduan terkait masalah tersebut. Jumlah itu sekitar 25\% dari total pengaduan di bidang pendidikan sebanyak 1.480 kasus. Perundungan yang disebut KPAI sebagai bentuk kekerasan di perguruan tinggi, mengalahkan tawuran pelajar, diskriminasi pendidikan, ataupun pungutan liar (Republika, 15 Oktober 2014)

Data di atas menunjukkan bahwa masalah perundungan merupakan salah satu permasalahan yang penting untuk diperhatikan dalam dunia pendidikan. Wiyani (2012) mengungkapkan bahwa tindakan perundungan cenderung kurang diperhatikan atau diabaikan dalam kehidupan sehari-hari. Masih banyak yang menganggap bahwa perundungan merupakan tindakan yang tidak berbahaya, khususnya di dikalangan mahasiswa perguruan tinggi. Padahal, tindakan perundungan apabila dibiarkan terus-menerus dapat memberikan dampak negatif bagi korbannya dan mengganggu proses pembelajaran (Simbolon, 2012). Dampak yang ditimbulkan dari tindakan perundungan, korban perundungan dapat mengalami gangguan pada fisik maupun psikologisnya.

Menilik poin di atas, penelitian ini bertujuan untuk menganalisis perundungan yang terjadi di Fakultas Komunikasi Universitas Islam 45 Bekasi dari sisi komunikasi verbal dan non- 
verbal serta dampak-dampak yang ditimbulkan oleh perundungan. Berikut adalah perumusan masalah dari penelitian ini:

1. Apa saja bentuk-bentuk komunikasi dan tindakan perundungan di kalangan mahasiswa Fakultas Komunikasi, Sastra, dan Bahasa UNISMA Bekasi?

2. Apa dampak yang ditimbulkan dari tindakan perundungan dikalangan mahasiswa Fakultas Komunikasi, Sastra, dan Bahasa UNISMA Bekasi?

\section{KERANGKA PEMIKIRAN}

\section{Komunikasi verbal dan nonverbal}

Simbol atau pesan verbal adalah semua jenis simbol yang menggunakan satu kata atau lebih. Hampir semua rangsangan wicara yang kita sadari termasuk ke dalam kategori pesan verbal di sengaja, yaitu usaha-usaha yang dilakukan secara sadar untuk berhubungan dengan orang lain secara lisan. Suatu sistem kode verbal disebut bahasa. Bahasa dapat didefinisikan sebagai seperangkat simbol, dengan aturan untuk mengombinasikan simbol-simbol tersebut, yang digunakan dan dipahami suatu komunitas. Bahasa verbal adalah sarana untuk menyatakan pikiran, perasaan, dan maksud kita. Bahasa verbal menggunakan kata-kata yang merepresentasikan berbagai aspek realitas individual kita (Mulyana, 2007).

Komunikasi verbal dapat dibedakan menjadi komunikasi lisan dan komunikasi tulisan. Komunikasi lisan dapat didefinisikan sebagai suatu proses di mana seorang pembicara berinteraksi secara lisan dengan pendengar untuk mempengaruhi tingkah laku penerima. Komunikasi tulisan adalah apabila keputusan yang dituliskan oleh seseorang yang disandikan dalam simbol- simbol yang dituliskan pada kertas atau pada tempat lain yang bisa dibaca, tertulis, yang dapat berupa surat, memo, buku petunjuk, gambar, laporan. Sedangkan lisan dapat berupa percakapan antar pribadi secara tatap muka, atau melalui telpon, radio, televisi, dan lain-lain.

Di lain pihak, pesan nonverbal adalah semua isyarat yang bukan katakata. Menurut Larry A Samovar dan Richard E Porter, komunikasi nonverbal mencakup semua rangsangan (kecuali rangsangan verbal) dalam suatu setting komunikasi, yang dihasilkan oleh individu dan penggunaan lingkungan oleh individu, yang mempunyai nilai pesan potensial bagi pengirim atau penerima. Sehingga dapat disimpulkan bahwa komunikasi nonverbal merupakan merupakan perilaku yang disengaja dan tidak disengaja sebagai bagian dari sebuah peristiwa komunikasi secara keseluruhan dan pengiriman pesan nonverbal kepada orang lain tanpa disadari memiliki makna bagi orang tersebut.

\section{Perundungan}

Righby dalam Anesty (2009) merumuskan perundungan sebagai sebuah hasrat untuk menyakiti yang diperlihatkan dalam aksi sehingga menyebabkan seseorang menderita. Aksi tersebut dilakukan secara langsung oleh seseorang atau sekelompok orang yang lebih kuat dan tidak bertanggung jawab. Tindakan perundungan dilakukan secara berulang-ulang dan dengan perasaan senang (Astuti, 2008: 3). Olweus (1993) 
berargumen bahwa mahasiswa yang menjadi korban perundungan sulit untuk mempertahankan diri. Perundungan merupakan perilaku negatif yang mengakibatkan seseorang dalam keadaan tidak nyaman/terluka dan biasanya terjadi berulang-ulang "repeated during successive encounters".

Terdapat tiga kategori praktik perundungan yaitu: (a) fisik,(b) nonfisik,(c) mental atau psikologis. Contoh perundungan fisik adalah menampar, menimpuk, menjegal, menginjak kaki, meludahi, memalak, melempar dengan barang, dan menghukum. Di lain pihak, perundungan verbal adalah memaki, menjuluki, menghina, meneriaki, mempermalukan di hadapan umum, menuduh, menyoraki, menebar gosip, serta memfitnah. Sedangkan tindakan perundungan mental adalah memandang sinis, memandang penuh ancaman, mempermalukan di hadapan umum, mendiamkan, mengucilkan, mempermalukan, meneror melalui pesan pendek telepon genggam atau email, memelototi, serta mencibir (Sejiwa, 2008).

Perundungan menyebabkan
dampak negatif kepada korban-
korbannya. Carlisle (2007) memaparkan
beberapa dampak perundungan antara
lain perasaan kesepian, rasa malu, rasa
tidak aman, bahkan luka-luka fisik pada
korban perundungan fisik. Selain itu,
Righby (2002) menyatakan dampak
negatif perundungan seperti
kesejahteraan psikologis yang rendah,
menarik diri dari pergaulan dan
cenderung untuk membolos dari
perguruan tinggi, serta tingkat kecemasan

yang sangat tinggi sehingga korban merasa depresi dan memiliki dorongan untuk melakukan tindakan bunuh diri.

\section{Dampak Perundungan}

Tindakan perundungan, merupakan tindak kekerasan yang bisa menimbulkan kerugian pada korban, baik dalam hal fisik maupun psikis. Carlise menguraikan efek pengalaman menjadi korban perundungan yang terjadi pada mahasiswa yaitu:

1. Psikologis, perasaan kesepian, malu, timbul perkara untuk balas dendam, cemas, mudah merasa tertekan, tidak percaya diri, kesulitan membaur dengan kelompok, dan sebagainya.

2. Dampak psikologis juga meliputi rasa takut, rasa tidak aman, dendam, dan menurunya semangat belajar mahasiswa, daya konsentrasi, kreatifitas, hilang inisiatif, daya tahan (mental), menurunya rasa percaya diri, stress, depresi, dan sebagainya. Dan dalam jangka panjang bisa berakibat pada penurunan prestasi dan perubahan perilaku mahasiswa.

3. Fisik, mengakibatkan organ-organ tubuh mahasiswa mengalami kerusakan, seperti memar, luka-luka, dan sebagainya. Secara spesifik, Rigby membagi dampak psikologis korban perundungan menjadi empat kategori, yaitu; (a) memiliki kesejahteraan psikologis yang rendah. pada ketegori ini kesadaran mental korban menjadi lemah, namun kodisi ini tidak terlalu berbahaya. Perasaan tidak bahagia muncul pada diri korban, selain juga perasaan mudah marah, sensitif, 
serta harga dirinya yang rendah, (b) memiliki pandangan dan kemampuan sosial yang rendah. korban yang berada pada kategori ini seringkali menarik diri dari pergaulan, dan sebaliknya lebih suka mengisolasi diri dari dan cenderung untuk membolos perguruan tinggi, (c) psychological distress, pada kategori ini korban memiliki tingkat kecemasan yang sangat tinggi. Korban merasa depresi dan memiliki dorongan untuk melakukan tindakan bunuh diri, (d) dampak negatif secara fisik, misalnya luka-luka akibat serangan fisik, serta penyakit lainnya seperti sakit kepala, deman, flu dan batuk.

\section{METODE PENELITIAN}

Penelitian ini menggunakan metode penelitian kualitatif yang merupakan upaya untuk menghasilkan data deskriptif. Penelitian kualitatif adalah tradisi tertentu dalam ilmu pengetahuan sosial yang secara fundamental tergantung pada pengamatan pada manusia dalam kawasannya sendiri dan berhubungan dengan orang-orang tersebut dalam bahasanya dan dalam peristilahannya (Maleong, 2011). Disamping data sekunder, penelitian kualitatif juga didapat dari sumber yang primer, yaitu data atas informasi yang diperoleh dari suatu wawancara langsung dari sumber informan. Data ini diperoleh melalui wawancara dengan subjek penelitian. Dalam mewawancarai narasumber, seorang peneliti harus objektif dalam melakukan penelitiannya sehingga dalam menganalisis data hasilnya dapat seakurat mungkin.

\section{HASIL DAN PEMBAHASAN}

\section{Tindakan Perundungan}

Berdasarkan wawancara yang dilakukan kepada mahasiswa, khususnya kepada teman-teman pelaku perundungan, perundungan difahami sebagai suatu tindakan kekerasan yang dilakukan oleh pihak yang kuat terhadap pihak yang lemah. Menurut Smith et al. (2003), perundungan adalah suatu aksi negatif yang secara intens bertujuan untuk mengintimidasi serta menyakiti orang lain. Tindakan Perundungan juga selalu dihubungkan dengan tindak kekerasan. Wujud tindakan perundungan terjadi dalam tiga kategori yaitu perundungan fisik, perundungan non fisik, dan perundungan mental (Sejiwa, 2008). Bila dilihat dari tiga kategori perundungan tersebut maka, ketiga kategori perundungan tersebut pernah dialami korban.

a) Perundungan fisik, seperti tindakan menampar, menimpuk, menjegal, menginjak kaki, meludah didepan korban, melempar dengan barang, berkelahi satu lawan satu.

b) Perundungan non fisik, seperti memaki, menjuluki, menghina, meneriaki, mempermalukan di hadapan teman-teman satu kelas, menuduh tanpa alasan yang kuat, menyoraki, menebar gosip, serta memfitnah korban

c) Perundungan mental atau psikologis, seperti memandang dengan sinis, memandang penuh ancaman, mempermalukan di hadapan umum, mendiamkan dengan tidak 
memberitahukan

informasi

mengenai matakuliah apakah mengenai tuga kelompok atau tugas pribadi, mengucilkan dengan tidak mengikutsertakan korban dalam group whatshApp kelas, dan mencibir. Menganggap korban "orang bodoh" dan tidak memiliki kemampuan apa-apa. Namun pandangan berbeda diungkapkan oleh PC, bahwa teman-teman di kelas awalnya tidak memandang bodoh GL, HW, dan IL, korbanlah yang membuat teman-teman dikelas melakukan perundungan kepada korban. Misalnya ketika ada tugas kelompok para korban tidak mau aktif bertanya dan bekerja sama dalam tim. Sehingga para pelaku tindakan perundungan pun menganggap korban tidak mampu mengerjakan tugas kelompok dengan baik dan menggap mereka bodoh dan itu terlihat dari pandangan mata teman-teman.

Tindakan perundungan yang dilakukan tentunya memiliki dampak yang negatif bagi pelaku dan korban perundungan, seperti yang diungkapkan oleh PC, teman sekelas korban :

“...dampaknya tidak adanya lagi kebersamaan atau memiliki sekutu/geng sendiri-sendiri baik dalam kelas maupun diluar kelas. Korban lebih bermain dengan berbeda fakultas atau jurusan dibandingkan jurusannya sendiri (menjauh secara teratur). Korban merasa nyaman dengan yang berbeda jurusan atau fakultas dibandingkan berbincangbincang dengan pelaku perundungan (mahasiswa dari satu jurusan)..."
Pada dasarnya baik pelaku dan korban perundungan menyadari bahwa tindakan perundungan dapat merugikan bagi mereka. Tindakan perundungan sebagai bentuk komunikasi yang menyampaikan pesan kepada korban perundungan bahawa pelaku dianggap sebagai "penindas" superior, dan harus dijauhi. Sementara bagi korban perundungan anggapan kerap muncul dari temanteman satu kelas, seperti, korban kurang bisa membaur diantara teman-teman sekelas, dianggap "bodoh" karena sikap kurang rasa percaya diri yang diperlihatkan oleh korban.

Sementara bagi korban sendiri dampak perundungan berupa; jarang mendapatkan informasi mengenai tugas yang diberikan oleh dosen, rasa sedih, rasa takut, dan rasa kecewa terhadap teman-teman satu angkatan. Penilaian negatif tidak hanya muncul dari temanteman satu angkatan melainkan dari adik angkatan kelas dan dari teman-teman yang berbeda jurusan atau program studi karena korban lebih sering dan nyaman berinteraksi serta berkomunikasi dengan teman-teman yang berbeda fakultas dan jurusan.

\section{Perundungan dalam Bentuk Komunikasi Verbal - Nonverbal}

Hingga saat ini di Universitas Islam ' 45 ' belum ada data statistik yang menginformasikan tentang jumlah tindakan perundungan yang dilakukan oleh mahasiswa kepada mahasiswa lainnya baik oleh senior kepada junior atau sesama teman satu angkatan, seperti yang terjadi pada mahasiswa Program Studi IK dengan inisial HW. Korban 
perundungan HW mengungkapkan bahwa dirinya kerap menjadi bahan ledekan oleh teman-teman satu angkatan, tidak saja dalam bentuk komunikasi verbal dengan penggunaan kata-kata ledekan dan makian. Perundungan dalam bentuk komunikasi verbal berupa penggunaan bahasa lisan berupa katakata, kalimat, dan unsur-unsur bahasa lainya. Menurut Baryadi (2012) bahwa berbahasa adalah bagian dari tingkah laku manusiawi dan dalam tingkah laku itu sangat mungkin orang melakukan sesuatu yang dapat dikategorikan sebagai serangan secara verbal, artinya serangan menggunakan kata-kata (verbal attack) kepada orang lain yang tidak lain merupakan kategori tindakan perundungan. Berikut ungkapan dari HW:

“ ...saya sering mendapat ledekan dari teman-teman saya. Tidak hanya satu orang saja yang meledek saya, lebih dari tiga orang, baik teman-teman yang lakilaki dan juga teman-teman yang perempuan. Biasanya yang meledek orangnya itu-itu aja sih. Padahal saya tidak pernah berbuat yang merugikan mereka. Tapi saya tidak tahu kenapa mereka suka meledek dan menekan saya."

Apa yang diungkapkan oleh HW dibenarkan oleh teman satu angkatan HW yang bernama PC, HW memang kerap mendapatkan tindakan perundungan dalam bentuk komunikasi verbal berupa kata-kata kasar yang meremehkan korban seperti kata "emang loe bisa", "kayak pinter aja", "kemana aja loe?", "masih hidup loe?" bahkan menjadi bulanbulanan, dan itu dilakukan ramai-ramai dengan saling sahut menyahut. Berikut ungkapan dari PC :

"tindakan perundungan juga dilakukan dalam bentuk verbal, yaitu para pelaku perundungan berbicara dengan nada yang tinggi, menunjuk-nujuk korban, mentertawakan korban".

Dampak perundungan secara lisan juga dirasakan korban dalam bentuk nilai yang dikeluarkan oleh dosen. Korban yaitu HW, GL dan IL mendapatkan nilai $\mathrm{D}$ dari dosen karena pelaku perundungan menyampaikan bahwa HW, GL dan IL tidak aktif dalam kegiatan yang ditugaskan oleh dosen bersangkutan. Padahal menurut korban, mereka sudah banyak berkontribusi dalam kegiatan tersebut seperti menjaga properti dengan menginap dilokasi kegiatan. Korban pun merasa kecewa terhadap dosen yang bersangkutan karena mempercayai sepenuhnya apa yang disampaikan oleh YG,ID,S,I,N,R, dan A (pelaku perundungan) tanpa mau mendengarkan apa yang disampaikan oleh HW, GL dan IL.

Tindakan perundungan juga terjadi dalam bentuk komunikasi nonverbal. Komunikasi nonverbal sendiri menurut Ruben dan Stewart (2005) memiliki beberapa saluran yaitu paralanguage, wajah dan gerakan tubuh (kinesics), sentuhan (haptics), penampilan fisik serta proximity (jarak) dan chonemics (waktu). Tindakan perundungan dalamb entuk komunikasi nonverbal yaitu dengan memperlihatkan pandangan mata yang menganggap korban "orang bodoh" dan tidak memiliki kemampuan apa-apa. Namun anggapan "orang bodoh" yang diperlihatkan oleh teman-teman dikelas bukan tanpa alasan. Menurut PC bahwa 
teman-teman awalnya tidak memandang bodoh GL, HW, dan IL, Korbanlah yang membuat teman-teman dikelas menilai korban sebagai "orang bodoh". Misalnya ketika ada tugas kelompok para korban tidak mau aktif bertanya dan bekerja sama dalam kelompok. Sehingga para pelaku tindakan perundungan pun menganggap korban tidak mampu mengerjakan tugas kelompok dengan baik dan menggap mereka bodoh dan itu terlihat dari pandangan mata temanteman.

"Pengakuan dalam kerja tim : temanteman selalu menganggap remeh hasil kerja dari korban, sehingga terkadang dalam tugas kelompok korban justru tidak diberi tugas. Informasi mengenai tugas, para korban sering terkadang tidak mendapat informasi mengenai tugas, sehingga mereka sering terlambat mengumpulkan tugas".

Perlakuan lain dari perundungan nonverbal dengan menunjuk-nujuk korban, mentertawakan korban. Selain itu juga GL, HW, dan IL mendapat pengucilan dari pelaku perundungan dengan tidak memasukan korban ke dalam group chat whatsApp sehingga ketika ada informasi dari dosen dan petugas administrasi Fakultas, para pelaku perundungan sering kali tidak memberitahukannya kepada korban. Menurut korban ada dua group chat yang dibentuk oleh teman-temannya yaitu group WA dan BBM, namun tidak satupun mereka diikutsertakan ke dalam group chat tersebut. Padahal group tersebut berisi informasi mengenai tugas, jadwal kuliah, perpindahan waktu atau jam matakuliah dan pengumuman lainnya. HW, GL dan IL pernah tidak diberitahu mengenai tugas matakuliah Pendidikan Kewarganegaraan, sehingga komponen nilai tugas menjadi 0 (nol) dan mereka tidak lulus matakuliah Pendidikan Kewarganegaraan. Selain tidak dimasukkan ke group, korban juga di asingkan di kelas. Bentuk pengasingan ini masuk ke dalam bentuk komunikasi nonverbal dalam hal membuat jarak (proximity). Padahal GL sudah berusaha mendekatkan diri dan bergabung dengan teman-teman dikelas dengan duduk satu baris ketika kuliah, namun biasanya teman-teman langsung pergi mencari tempat duduk yang lain.

Bentuk lain dari proximity juga terlihat dengan mengucilkan korban. Korban tidak dilibatkan dalam kegiatan pergi bareng oleh teman-teman seangkatan korban, misalnya ke Puncak, nonton bareng. Korban perundungan biasanya tahu teman-teman pergi ke Puncak, nonton film dari foto-foto di Facebook (FB).

Perundungan non verbal tidak hanya merugikan secara mental atau psikologi tapi juga secara materi. Pelaku perundungan pernah menendang telpon genggam milik IL. GL mengungkapkan bahwa pernah suatu kali pada saat perkuliahan berlangsung di kelas, telpon genggam IL ditendang. oleh NS, apakah itu sengaja atau tidak, saya tidak tahu, dan saya benar-benar marah. Selain itu menurut GL, HW juga pernah di dorong oleh ID di kelas.

Berbeda dengan HW, FS yang diduga korban perundungan dari Program Studi SI memiliki sedikit cerita yang berbeda. FD diperlakukan oleh teman sengkatannya berbeda dengan HW, GL, dan IL dari program studi IK. FD 
merupakan mahasiswa pindahan dari universitas lain dan sejak bergabungnya FD ke program studi SI, FD dinilai berperilaku aneh oleh teman-temannya di dalam kelas. Hal ini diungkapkan oleh BQ, teman FD yang menyatakan bahwa perilaku dari FD dianggap aneh dan memiliki pendapat yang berbeda dari kebanyakan teman-temannya di kelas. Selain itu FD juga jarang bergabung dengan teman-temannya di kelas. Setiap sehabis matakuliah usai, FD biasanya langsung pulang atau entah kemana. Berbeda dengan teman-teman sekelasnya yang lebih memilih untuk tidak langsung pulang melainkan mengobrol terlebih dahulu atau kumpul bareng. Perilaku FD ini yang membuat teman-teman satu kelasnya cenderung mengucilkan FD dan setiap kali FD mengungkapkan pendapatnya dikelas, teman-teman FD akan mengarahkan pandangan ke FD dengan mimik wajah yang memperlihatkan keanehan dengan argumen yang disampaikan oleh FD.

Perilaku FD juga mendapat perhatian dari dosen mata kuliah yang mengajar di kelas FD. Bapak RB mengungkapkan pendapatnya tentang FD bahwa:

"Secara akademik sih FD biasa saja, bahkan cenderung tidak terlalu bagus. FD cenderung kurang bergabung dengan teman-temannya. Bahkan temantemannya juga menganggap aneh FD, karena punya pandangan yang berbeda jika ditanya tentang sesuatu hal ketika di kelas."

Sebenarnya tindakan pelaku perundungan kepada korban pada awalnya tidak sengaja dilakukan dan tidak benar-benar berniat dilakukan, karena pada awal perkuliahan yakni pada semester pertama pelaku dan korban perundungan sering kali melakukan komunikasi secara lisan dengan meledek atau bahkan bercanda dengan bahasa yang kasar. Namun tindakan perundungan ini justru terus berlanjut karena korban yang justru membuka peluang yang membuat pelaku semakin meledek bahkan mengucilkan korban. Contoh ketika ada tugas kelompok para korban tidak mau aktif bertanya dan bekerja sama dalam tim. Sehingga para pelaku pun makin mengucilkan korban dan menganggap korban tidak mampu mengerjakan tugas kelompok dengan baik. Ditambah lagi korban perundungan tidak berusaha untuk melawan pelaku perundungan atau diam saja dengan tindakan perundungan yang dilakukan oleh pelaku sehingga pelaku semakin gencar dan tampak menikmati tindakan perundungan tersebut seperti yang diungkapkan oleh PC:

"Ketika korban datang, salah satu pelaku mulai meledeknya kemudian temanteman pelaku yang lain pun ikut-ikutan meledek. A: 'kemana aja lo?', B: 'masih hidup lo?'."

Umumnya pelaku perundungan berjenis kelamin laki-laki. Hal ini senada dengan hasil survei yang dilakukan oleh Latitude News pada 40 negara. Salah satu faktanya adalah bahwa pelaku perundungan biasanya para mahasiswa laki-laki. Sedangkan mahasiswi lebih banyak melakukan tindakan perundungan dalam bentuk komunikasi verbal seperti menggosip ketimbang melakukan tindakan perundungan dalam bentuk komunikasi nonverbal seperti 
menendang, memukul dan lain sebagainya (Pratiwi, 2014).

Atas dasar atau alasan apapun, tindakan perundungan tidak dapat dibenarkan, karena apabila dibiarkan berlangsung terus menerus, efek perundungan bagi kedua belah pihak baik bagi korban maupun pelaku tindakan perundungan akan mengganggu proses belajar mengajar. Menurut Suryabrata dalam Wiyani (2012) pada usia 18 tahun sampai 25 tahun disebut sebagai usia mahasiswa sebenarnya. Pada usia tersebut mahasiswa digolongkan dalam masa dewasa awal. Mahasiswa merupakan peserta didik yang sedang mengikuti proses belajar mengajar di perguruan tinggi. Rentang usianya berkisar antara 18-19 tahun sampai 24-25 tahun. Jadi berdasarkan usia, mahasiswa sudah masuk pada masa dewasa awal. Hal ini berarti bahwa pada usia itu seseorang sudah dianggap dewasa dan selanjutnya dianggap sudah mempunyai tanggungjawab terhadap perbuatanperbuatannya, yakni sudah dapat dikenai sangsi-sangsi pidana tertentu apabila melanggar peraturan hukum.

\section{Dampak Perundungan}

Hasil penelitian yang dilakukan di asrama Universitas A (Simbolon 2012), perundungan mengakibatkan korbannya menjadi putus asa, menyendiri, tidak mau bergaul, tidak bersemangat, bahkan berhalusinasi. Meskipun ejekan, cemoohan, olok-olok mungkin terkesan sepele dan terlihat wajar, namun pada kenyataannya, hal itu tidak sepenuhnya benar. Hal-hal tersebut dapat menjadi senjata tak kenal ampun yang secara perlahan namun pasti dapat menghancurkan seseorang. Aksi-aksi negatif dari tindakan perundungan dapat mengancam segala aspek kehidupan para korbannya. Apalagi jika tindakan perundungan mengarah pada aksi kekerasan fisik. Berikut adalah dampakdampak perundungan yang dianalisis dalam penelitian ini:

1. Perasaan cemas dirasakan oleh korban-korban seperti FL, HW, dan IL. Perasaan itu muncul pada saat mereka harus presentasi tugas di depan temantemannya. Seketika akan muncul kegugupan dan mudah merasa tertekan, dan tidak percaya diri terhadap hasil yang sudah dilakukan oleh korban. Korban juga merasa sulit untuk membaur dengan teman-teman seangkatannya atau temanteman lainnya. Seperti yang terjadi pada HW. HW merasa kesulitan memulai pertemanan dalam dunia nyata, tidak merasa percaya diri, dan sebagainya. Namun HW menjadi orang yang berbeda ketika berhadapan dengan dunia virtual, HW punya banyak teman. Dampak psikologis juga meliputi rasa takut, rasa tidak aman, dendam, dan menurunnya semangat belajar mahasiswa, daya konsentrasi, kreativitas, hilang inisiatif, daya tahan (mental), menurunnya rasa percaya diri, stres, depresi, dan sebagainya. Dalam jangka panjang, bisa berakibat pada penurunan prestasi dan perubahan perilaku mahasiswa. Hal ini dirasakan oleh GL yang sempat depresi dan malas datang ke kampus karena merasa dikucilkan oleh teman-temannya dan pernah berniat untuk pindah ke kampus lain.

"Efeknya dari perlakuan teman-teman ke saya, bikin saya males ke kampus, dan 
bikin saya mau pindah ke kampus lain. Karena segala tugas saya tidak dapet informasi dari teman-teman, saya dikucilkan. Sampai beberapa matakuliah saya tertinggal dan tidak lulus."

Dari prestasi yang didapatkan oleh korban perundungan menurut dosen pembimbing akademik HW, Kartini Rosmalah DK, hasilnya tidaklah bagus. Karena memang dari hasil evaluasi kehadiran HW, beliau sering tidak hadir, bahkan tidak aktif selama kurang lebih satu semester. Akibatnya, HW banyak tertinggal matakuliah dibandingkan dengan teman-temannya. Begitu juga dengan GL dan IL, walaupun prestasi GL dan IL tidak seburuk HW, karena kedua korban sudah mampu menyelesaikan kuliahnya. Berdasarkan hasil wawancara dengan GL, GL cenderung gagap hingga berkeringat jika mengalami tekanan.

2. Fisik, mengakibatkan organorgan tubuh mahasiswa mengalami kerusakan, seperti memar, luka-luka, dan sebagainya. Berdasarkan hasil wawancara dengan GL dan HW, korban pernah mengalami luka fisik karena adu fisik dengan para pelaku perundungan.

Penanganan perundungan yang dapat dilakukan oleh perguruan tinggi sebagai institusi pendidikan melalui kebijakan perguruan tinggi dengan cara membuat seperangkat peraturan tentang pencegahan, penghentian serta intervensi bagi korban maupun pelaku. Kebijakan lainnya adalah menerapkan serta menegakkan kerjasama, tanggung jawab seluruh sivitas akademika kampus (Milsom \& Gallo, 2006). Kebijakan yang dapat mengantisipasi tindakan perundungan antara lain melalui peningkatan pemahaman agama, diantaranya melalui penanaman karakter islami sebagai visi dari Universitas Islam'45' Bekasi, menghidupkan ajaran agama,serta menegakkan nilai-nilai etika di kampus kepada seluruh sivitas akademika.

Menurut Milsom dan Gallo (2006), kampus harus menciptakan aktivitas serta atmosfer untuk memunculkan kreativitas dan menciptakan rasa nyaman bagi mahasiswa. Aktivitas mahasiswa seperti kegiatan ekstrakurikuler menjadi pilihan yang dianggap paling tepat untuk penanganan tindakan perundungan. Selain itu, kegiatan yang telah menjadi program wajib di UNISMA seperti penanaman karakter islami melalui kegiatan BTQ (Baca Tulis Alquran), mentoring dirasakan cukup efektif untuk mencegah tindakan perundungan kepada sesama mahasiswa. Kebijakan antisipasi terhadap tindakan perundungan yang dilakukan oleh mahasiswa diharapkan mendapat dukungan oleh berbagai pihak di universitas. Upaya pencegahan perundungan memang harus menjadi perhatian semua pihak. Seluruh komponen yang terkait dengan lingkungan kampus antara lain mahasiswa, dosen, maupun orangtua harus punya peran untuk menghentikan perundungan.

\section{SIMPULAN}

Berdasarkan wawancara yang dilakukan kepada mahasiswa, khususnya kepada teman-teman pelaku perundungan, perundungan difahami sebagai suatu tindakan kekerasan yang dilakukan oleh pihak yang kuat terhadap pihak yang lemah. Tindakan Perundungan juga 
selalu dihubungkan dengan tindak kekerasan. Wujud tindakan perundungan yang dialami oleh mahasiswa berupa (a) perundungan fisik, seperti tindakan menampar, menimpuk, menjegal, menginjak kaki, meludah didepan korban, melempar dengan barang, berkelahi satu lawan satu; (b) perundungan non fisik, seperti memaki, menjuluki, menghina, meneriaki, mempermalukan di hadapan temanteman satu kelas, menuduh tanpa alasan yang kuat, menyoraki, menebar gosip, serta memfitnah korban; (c) perundungan mental atau psikologis, seperti memandang dengan sinis, memandang penuh ancaman, mempermalukan di hadapan umum, dan membuat jarak.

Perundungan dalam bentuk komunikasi verbal yang dialami oleh korban berupa penggunaan berupa kata-kata kasar yang meremehkan korban seperti kata "emang loe bisa", "kayak pinter aja", "kemana aja loe?", “masih hidup loe?” bahkan menjadi bulan-bulanan, dan itu dilakukan ramai-ramai dengan saling sahut menyahut. Sedangkan perundungan dalam bentuk komunikasi nonverbal berupa pandangan sinis pelaku terhadap korban, pandangan merendahkan korban dengan menganggap korban sebagai "orang bodoh", membuat jarak dengan korban dengan tidak mengikutsertakan korban dalam chat group, tidak diajak berdarmawisata, dijauhkan di kelas. Selain itu korban juga pernah mendapat tendangan, diludahi, dilempar dengan barang.

Tindakan perundungan tentu akan berdampak bagi pelaku maupun korban. Tindakan perundungan sebagai bentuk komunikasi menyampaikan pesan negatif kepada korban perundungan bahawa pelaku dianggap sebagai "penindas" superior, dan harus dijauhi. Sementara bagi korban perundungan anggapan kerap muncul dari temanteman satu kelas, seperti, korban kurang bisa membaur diantara teman-teman sekelas, dianggap "bodoh" karena sikap kurang rasa percaya diri yang diperlihatkan oleh korban. Universitas sebagai institusi pendidikan harus menciptakan kebijakan-kebijakan yang dapat mengantisipasi, menghentikan tindakan perundungan, dengan cara peningkatan pemahaman agama, diantaranya melalui penanaman karakter islami sebagai visi dari Universitas, menghidupkan ajaran agama,serta menegakkan nilai-nilai etika di kampus kepada seluruh sivitas akademika.

\section{UCAPAN TERIMA KASIH}

Terimakasih yang mendalam peneliti ucapkan kepada Universitas Islam 45 Bekasi yang mendukung peneliti dalam kegiatan penelitian. Ucapan terima kasih peneliti haturkan pula pada mahasiswa Fakultas Komunikasi, Sastra, dan Bahasa Universitas Islam 45 Bekasi yang telah bersedia menjadi informan dalam penelitian ini. Terima kasih pada pihak lain yang selama ini telah membantu proses penyelesaian penelitian ini.

\section{DAFTAR PUSTAKA}

Baryadi. Praptomo I. 2012. Bahasa, Kekuasaan, dan Kekerasan. Universitas Sanata Darma: Yogyakarta

Bungin, B. 2011. Konstruksi Sosial Media Massa. Kencana Prenada: Jakarta. 
Carlisle, N. 2007. School Bullying: Do

Adults Survivors Perceive Long Term Effects of Traumatology. Edisi November 2007.

Christin. 2009. Dampak psikologis bullying pada siswa SMA. Gunadarma University: Yogyakarta.

Control, D. 2013. Bullying and Suicide: A Public Health Approach. Journal of Adolesent Health.

Devito J.A. 2010. Komunikasi Antar Manusia. Edisi Kelima. Profesional Books: Jakarta .

Donegan, R. 2012. Bullying and Cyberbullying: History, Statistics, Law, Prevention and Analysis.The Elon Journal of Undergraduate Research in Communications. Vol. 3 No. 1: 33-42.

Effendy, O. U. 2003. Ilmu, Teori dan Filsafat Komunikasi. Citra Aditya Bakti: Bandung.

Harper, D. Online Etymology Dictionary [internet]. Tersedia dari http://www.etymonline.com/index.php?a llowed_in_frame $=0 \&$ search $=$ bully\&sear chmode $=$ none.

Kamus Besar Bahasa Indonesia. Tindak [internet]. Tersedia dari http:// (http://kbbi.web.id/intimidasi).

Kriyantono, R. 2006. Teknis Praktis Riset Komunikasi. Media Kencana Prenada: Jakarta.

Lewis, Philip V. 1987. Organizational Communication : The Essence of Effective Management. John Willey \& Sons: New York.
Maleong, LJ. 2009. Metodologi Penelitian Kualitatif. Remaja Rosdakarya: Bandung.

Mantra B.I. 2000. Demografi Umum. Pustaka Pelajar: Yogyakarta.

Muhammad, A. 2005. Komunikasi Organisasi. Jakarta: Bumi Aksara.

Mulyana, D. 2005. Ilmu Komunikasi Sutu Pengantar. Bandung: Remaja Rosda Karya.

Neuman WL. 2003. Social Research Methods: Qualitative and Quantitative Approaches. 5th Ed. Pearson Education Inc: Boston.

Olweus, D. 1978. A useful evaluation design and effects of the Olweus bullying prevention program. Psychology, Crime and La. Guilford Publications: New York.

Olweus, D. Peer harassment: a critical analysis and some important issues [internet]. Tersedia dari http://www.olweus.org/public/bullying.p age.

Olweus D. 1993. Bullying at School: What We Know and What We Can Do. Blackwell: Cambridge, MA.

Pratiwi, A. Kasus Bullying di Indonesia [internet]. Tersedia dari https://teen.kapanlagi.com/girls/pubertas /kasus-bullying-di-indonesia261e53.html.

Purwata H. 2014. Mahasiswanya Tewas, UIN Suka Yogya Kutuk Aksi Serangan!. Republika : Jakarta.

Rakhmat, Jalaluddin. 2005. Psikologi Komunikasi (Edisi Revisi). PT Remaja Rosdakarya: Bandung. 
Righby, K. 2002. New Perspective On Bullying. Jessica: London.

Riauskina, I, Djuwita, R, Soesetia, S.R. 2005. Gencet-Gencetan" di mata siswa/siswi kelas 1 SMA: Naskah Kognitif tentang arti scenario, dan dampak "Gencet-Gencetan". Jurnal Psikologi Sosial. Vol. 12 No. 1: 1-13.

Ruben, Brent D, Stewart, Lea P. 2005. Communications and Human Behaviour. Alyn and Bacon; USA

SEJIWA (Yayasan Semai Jiwa Amini) (2008). Mengatasi kekerasan dari sekolah dan lingkungan anak. Grasindo: Jakarta.

Simbolon, M. 2012. Perilaku Bullying pada Mahasiswa Berasrama. Jurnal Psikologi. Vol. 39 No.2: 1-20.
Susanto, S. Astrid. 1977. Komunikasi dalam Teori dan Praktek. Bandung: Bina Cipta.

Tanjung A. Langkah Tegas STIP Marinda Pasca Kematian Dimas Dikita Handoko [internet]. Tersedia dari http://www.merdeka.com/peristiwa/lang kah-tegas-stip-marunda-pasca-kematiandimas-dikita-handoko.htmlAgib Tanjung | Selasa, 29 April 2014 05:05

Wiyani, N. A. 2012. Save our children from school bullying. AR-RUZZ Media: Yogyakarta.

Yusuf I. 2007. Arogansi dan Kekerasan di IPDN. Kompas: Jakarta. 